\title{
PENGARUH IMPLEMENTASI KEBIJAKAN AUDIT PENERIMAAN NEGARA BUKAN PAJAK (PNBP) TERHADAP KINERJA AUDITOR PADA PUSAT PENGEMBANGAN DAN PENATARAN GURU IPA KOTA BANDUNG
}

\author{
Nanang Suparman \\ FISIP UIN SGD Bandung \\ Email: n.suparman69@gmail.com
}

\begin{abstract}
TheNon-Tax Revenue policy as an implementative rules from laws, is an policy in attempt for collection and managing mechanism of non-tax revenue. Consequently, such policy has determined various preventive and repressive rules on deviation behavior toward state financial righats. The effective of audit policy of all activities link that must be applied by such performance.Both from organizational, interpretative, and application aspects. Owned professional ethics of auditors to the adherence to the policy in order to improve the performance of supervisory auditor.Therefore, it is carried out an evaluation on auditor supervisory performance throughout state financial rights security indicators, adherence on auditing administrative policy and process. Research variables consist of activities in implementation of non-tax state revenue audit policy, namely: organizing, interpreting, and application as independent variables, meanwhile its auditor supervisory performance is observed from organizational intern controlling system, namely:protection of state financial rights, adherence on auditing administrative policy and process as dependent variables.
\end{abstract}

Key words: Non-Tax, Implementation, Auditing

\section{PENDAHULUAN}

Dalam rangka melaksanakan prinsip Anggaran Pendapatan dan Belanja Negara yang dinamis dan meningkatkan kemampuan keuangan Negara, maka perlu diciptakan langkah strategis dengan memberdayakan sumber-sumber penerimaan negara untuk membiayai pembangunan nasional.Penerimaan pemerintah dari sektor penerimaan negara bukan pajak dapat dijadikan salah satu sumber penerimaan andalan selain pajak. Tentunya untuk mewujudkan hal tersebut, diperlukan strategi-strategi dalam rangka menjadikan penerimaan negara bukan pajak sebagai sumber penerimaan pemerintah yang strategis. Terutama yang dihasilkan oleh lembagalembaga publik.
Khusus mengenai tantangan terhadap kinerja pemerintah dalam konteks pelaksanaan implementasi kebijakan publik yaitu auditasi penyelenggaraan pemungutan PNBP, maka diperlukan suatu strategi untuk efektivitas dari pengimplementasian kebijakan tersebut.

Penerimaan negara bukan pajak dalam struktur APBN dibagi dalam pos-pos sebagai berikut: Penerimaan pendidikan, Penerimaan penjualan, Penerimaan jasa, Penerimaan kejaksaan dan peradilan, Penerimaan kembali dan lain-lain, Laba BUMN dan Penerimaan bukan pajak diluar negeri Prawiro (2006:8).

Dari banyaknya pos-pos penerimaan tersebut, sumber penerimaan ini sangat siginifikan sebagai sumber pembiayaan pembangunan. Untuk itu diperlukan kecermatan administrasi 
pengelolaannya serta integritas moral pelaksana/pejabat yang mengurus penerimaanpenerimaan tersebut. Sebagai pedoman untuk melaksanakan proses tersebut diperlukan suatu komitmen yang tinggi dari aparat pelaksana dalam rangka mengamankan hak keuangan negara, salah satunya dengan mengadakan audit penggunaan penerimaan tersebut. Oleh karena itu, dalam rangka pengelolaan penerimaan negara bukan pajak (PNBP) ini agar dapat terlaksana dengan baik juga tergantung pada integritas moral dari para auditor. Pelaksanaan audit merupakan aktivitas akuntansi, sebagaimana dinyatakan oleh Rudi dan Lestari (2010), audit sebagai bentuk analitis dalam pengumpulan dan pengolahan data keuangan yang penting untuk kemudian disampaikan dalam bentuk laporan atau ikhtisarikhtisar yang dapat dipakai untuk pengambilan keputusan. Berdasarkan pengertian tersebut, audit penerimaan negara bukan pajak juga memiliki bentuk analitis yang sama dengan bentuk analitis dalam pengertian akuntansi tersebut, dengan demikian dapat disimpulkan bahwa audit penerimaan negara bukan pajak adalah pemeriksaan akuntansi.

Berdasarkan prinsip-prinsip akuntansi yang berlaku umum, maka efektivitas suatu implementasi kebijakan terhadap pencapaian kinerja oleh implementator kebijakan tersebut dapat diukur dengan aspek-aspek pengendalian intern pada organisasi yang menjadi objek dalam penelitian ini. Hal ini sesuai dengan pengertian dari pengendalian intern sebagaimana dinyatakan oleh Herryanto dan Toly (2013) bahwa: Pengendalian intern yang baik meliputi rencana organisasi, metode, kebijaksanaan yang terkoordinasi dalam suatu organisasi untuk mengamankan harta kekayaan, menguji ketetapan sampai seberapa jauh data akuntansi dapat dipercaya, menggalakkan efisiensi usaha dan mendorong ditaatinya kebijaksanaan.

Berdasarkan pengertian tersebut, seluruh aktivitas pengorganisasian, penginterpretasian dan pengaplikasian kebijakan audit penerimaan negara bukan pajak harus diarahkan untuk mengungkap bagaimana prinsip-prinsip pengendalian intern dilaksanakan oleh para auditor. Sehingga hasil dari pengendalian intern tersebut dapat dijadikan input bagi penentuan hasil-hasil dari audit tersebut. Dengan kata lain, pengendalian intern tersebut harus menjadi arah dan tujuan dari implementasi kebijakan audit itu sendiri, sehingga hasilnya dapat dijadikan sebagai indikator kinerja bagi auditor dalam melaksanakan audit, tentunya untuk mendukung hal ini diperlukan kajian teoritis serta argumentasi yang kuat.

Pemilihan Pusat Pengembangan Penataran Guru IPA kota Bandung sebagai objek penelitian karena institusi tersebut perangkat kerja pusat yang diperbantukan di daerah (Provinsi Jawa Barat) yang melakukan pembinaan dan peningkatan kualitas pendidik. Disamping itu, PPPG IPA Bandung memiliki sarana tempat 
pelatihan/penataran dan mess (wisma) yang bisa juga dimanfaatkan oleh pihak luar baik pemerintah maupun swasta atau masyarakat. Sehubungan dengan potensi yang dimiliki oleh PPPG IPA Bandung tersebut, maka diperlukan suatu strategi implementasi yang jelas dalam pengelolaan dana tersebut. Karena antara target PNBP yang ditetapkan sebagai PAGU PNBP tersebut, dengan jumlah yang disetor ke kas negara realisasinya tidak sesuai dengan target dari pagu tersebut, hal ini menyebabkan perlunya implementasi kebijakan audit PNBP yang konsisten.

Konsistensi dari implementasi kebijakan audit PNBP tersebut, ditentukan oleh implementator dari kebijakan tersebut. Dalam konteks ini, implementator kebijakan audit PNBP adalah auditor sebagai agen yang memmiliki wewenang terhadap pengawasan dari pelaksanaan kegiatan yang mengacu kepada kebijakan tersebut. Oleh karena itu, auditor harus professional dan objektif dalam melaksanakan tugasnya sebagai agen dari kebijakan tersebut. Selain itu, auditor juga harus memiliki integritas moral dan komitmen untuk melaksanakan auditasi tersebut. Jadi kinerja pengawasan auditor ditentukan oleh proses dari pemgawasan auditor itu sendiri.

Dari fenomena di atas, dapat dilihat bahwa penerimaan negara bukan pajak pada satuan kerja PPPG IPA Bandung, mengalami stagnasi dan cenderung terjadi penurunan setiap tahunnya, yaitu sebesar Rp. 738.329.071 pada tahun 2012 dan Rp. 698.689.199 pada tahun 2013 (menurun sebesar 17,78 \%).. Penerimaan ini sebagian besar digunakan untuk biaya operasional pada Pusat Pengembangan Penataran Guru (PPPG) IPA Kota Bandung serta disetor ke kas negara, tentunya teknis administrasinya berdasarkan peraturan internal yang berlaku sedangkan apabila mengacu kepada Undang-Undang PNBP seluruh pendapatan PNBP harus disetor ke kas negara dalam waktu 1x 24 jam. Adapun alokasi penggunaan dana PNBP ini, adalah untuk biaya operasional asset-aset dari sumber-sumber PNBP itu sendiri, dalam hal ini perawatan dan operasional mess bagi peserta pelatihan pada PPPG IPA Kota Bandung.

Penelitianinibertujuanuntukmengetahuipenga ruh antara implementasi kebijakan audit penerimaan negara bukan pajak melalui dimensi pengorganisasian, penginterpretasian dan pengaplikasian terhadap kinerja pengawasan auditor.

\section{LANDASAN TEORITIS}

Dalam penelitian ini untuk melihat kompleksitas pengaruh antara implementasi kebijakan audit penerimaan negara bukan pajak terhadap kinerja pengawasan auditor, maka digunakan pendekatan teori-teori yang mendukung terlaksananya implementasi kebijakan tersebut, yaitu sebagai berikut : 
a. Teori kebijakan publik, karena teori ini digunakan untuk melakukan analisis kebijakan publik dan penilaian terhadap pilihan publik dalam penetapan kebijakan publik.

b. Teori Organisasi, karena teori ini digunakan untuk menganalisis perbedaan kepentingan antar organisasi dalam penetapan kebijakan publik.

c. Perspektif teori kesisteman, digunakan dalam rangka melakukan analisis evaluasi kebijakan publik secara menyeluruh. Sehingga cara pandang kesisteman yang bersifat komprehensif digunakan dalam penelitian ini.

Menurut Jones (2014) aktivitas-aktivitas dalam implementasi kebijakan publik terdiri dari :

a. Organisasi: pembentukan atau penataan kembali sember daya, unit-unit serta metode untuk menjadikan program berjalan.

Sesuai dengan pendapat dari Gerth \& Mills (Jones, 2014), untuk aktivitas pengorganisasian tersebut, birokrasi umumnya memiliki tiga elemen otoritas (beraucratic authority) yaitu ; (1) Aktivitas (2) Otoritas (3) Metode.

b. Interpretasi: menafsirkan agar program (seringkali dalam hal status) menjadi rencana dan pengarahan yang tepat dan dapat diterima serta dilaksanakan.

Terhadap definisi ini, lebih lanjut Mazmanian \& Sabatier (Jones, 2014) mengemukakan bahwa :

Penginterpretasian adalah proses penterjemahan terhadap isi undang-undang dan menjabarkannya kedalam arah dan perencanaan yang layak dan dapat diterima serta dilakukan melalui variabilitas sosial, politik, legal dan kondisi organisasi, yang diperinci kedalam; (1) Mudah tidaknya masalah dikendalikan (2) Kemampuan kebijkaksanaan (3) Variabel diluar kebijksanaan.

c. Aplikasi: ketentuan rutin dari pelayanan, pembayaran atau lainnya yang disesuaikan dengan tujuan atau perlengkapan program.

Pengertian yang dikemukan oleh Jones tersebut, dikembangkan lagi oleh Murray Edelman (Jones, 2014) yang menyatakan bahwa :

Pengaplikasian ini adalah suatu proses yang dinamis karena keterkaitannya dengan aktivitas-aktivitas kebijakan oleh hubungan antar manusia yang melaksanakan pekerjaannya sehingga dalam proses tersebut akan muncul apa yang dinamakan; (1) Pengambilan peran secara timbal balik (2) Aturan yang berlaku (3) Konflik.

Ketiga aktivitas di atas, mencerminkan suatu konteks hubungan kausalitas antara kebijakan publik sebagai suatu proses dari tindakantindakan sistematis dalam pengorganisasian, interpretasi dan aplikasi dengan dampak yang ditimbulkannya Iterhadap sesuatu (to give practice effect to). Dalam penelitian ini, adalah terhadap kinerja pengawasan yang dilakukan oleh 
JURNAL AKUNTANSI DAN PERPAJAKAN., Vol. 3, No. 1, Tahun 2017

auditor berdasarkan implementasi dari kebijakan audit PNBP.

\section{Kinerja Pengawasan Auditor dari Perspektif Teori Organisasi}

Untuk dapat menentukan kinerja yang dihasilkan dari pengimplementasian kebijakan publik, dapat ditinjau dari pendekatan analisis terhadap arah dan tujuan dari implementasi kebijakan tersebut. Dalam konteks ini, implementasi kebijakan audit yang dilakukan oleh para auditor dilingkungan Departemen Pendidikan Nasional RI. Berdasarkan perspektif teori sistem, pendekatan yang dapat digunakan adalah model input-transformasi-output, E.kast (2010:146) mengemukakan bahwa “...dalam hubungan yang dinamis dengan lingkungannya, organisasi menerima berbagai masukan (inputs), mengubah input itu dengan berbagai cara (proses), dan mengeluarkan outputs".

Dari konsep dan teori di atas, bahwa untuk menentukan arah dan tujuan pengimplementasian suatu kebijakan, khususnya kebijakan audit PNBP maka dapat diarahkan sebagai instrumen pengandalian intern dalam suatu organisasi yang mengelola PNBP. Terkait dengan hal tersebut, La Midjan dan Susanto $(2009: 45)$ menyatakanbahwaprinsip-prinsip dari pengendalian intern tersebut hendaknya menjadi arah dan tujuan dari dilakukannya auditing. Secara rinci prinsip-prinsip pengendalian intern tersebut terdiri dari :
1. Mengamankan hak keuangan negara

Apabila tidak dilindungi dengan sistem pengendalian intern yang memadai, maka aktiva ata aset negara dapat dicuri dan disalahgunakan baik dengan sengaja ataupun tidak sengaja.

2. Ketaatan pada Kebijakan yang digariskan Undang-undang

Dalam hal ini, sistem dan prosedur yang telah ditetapkan harus ditaati oleh setiap stakeholders yang terkait didalamnya.

3. Menguji ketelitian dan kebenaran data akuntansi

Aspek ini berkaitan dengan kemampuan audit untuk mendapatkan informasi yang dapat dipercaya kebenarannya (proses administrasi auditing).

\section{METODE}

Metode penelitian yang digunakan adalah pendekatan kuantitatif deskriptif dengan menggunakan analisis statistik parametrik, yaitu melihat pengaruh implementasi kebijakan audit penerimaan negara bukan pajak terhadap komitmen auditor. Analisis data deskriptif deskriptif digunakan dalm penelitian ini untuk mendeskripsikan data pada variabel penelitian, terutama untuk melihat gambaran umum tanggapan dari responden.

Adapun langkah-langkah yang dilakukan untuk analisis deskriptif ini adalah sebagai berikut: 
JURNAL AKUNTANSI DAN PERPAJAKAN., Vol. 3, No. 1, Tahun 2017

1. Setiap indikator oleh responden diklasifikasikan dalam lima alternatif jawaban. Peringkat jawaban setiap indikator diberi skor antara 1 sampai 5.

2. Untuk mendeskripsikan jawaban responden digunakan statistik deskriptif seperti distribusi frekuensi dan ditampilkan dalam bentuk tabel.

3. Untuk menjawab deskripsi setiap variable dimensi penelitian ini digunakan kriteria penilaian kategori sangat tinggi, tinggi, cukup tinggi, rendah, dan sangat rendah. Dengan ketentuan sebagai berikut:

- Skor minimum $(\%) \quad=1 / 5 \times 100=20 \%$

- Skor maksimum(\%) =5/5 x $100=100 \%$

- Rentang (\%)

- Interval (\%) $=100 \%-20 \%=80 \%$ $=80 \%: 5=16 \%$

\section{HASIL PENELITIAN DAN ANALISIS}

Berdasarkan data sekunder berupa dokumen, hasil kuesioner, dan wawancara dengan penyelenggara, penerimaan negara bukan pajak pada satuan kerja PPPG IPA Bandung, mengalami stagnasi dan cenderung penurunan berdasarkan data internalyang dilaporkan setiap tahunnya, terhadap pencapaian kinerja seperti itu tidak ada tindakan auditasi dalam bentuk investigasi atas kebenaran data yang disampaikan. Kinerja Auditor sebatas mencatat dan merekapitulasi data yang diberikan oleh auditee dan tidak ada rekomendasi-rekomendasi sanksi yang diterbitkan. Penerimaan ini sebagian besar digunakan untuk biaya operasional pada Pusat
Pengembangan Penataran Guru (PPPG) IPA Kota Bandung serta disetor ke kas negara, tentunya teknis administrasinya berdasarkan peraturan perundangan yang berlaku. Alokasi penggunaan dana PNBP ini, adalah untuk biaya operasional asset-aset dari sumber-sumber PNBP itu sendiri, dalam hal ini perawatan dan operasional mess bagi peserta pelatihan pada PPPG IPA Kota Bandung.

Dari hasil uraian diatas, bahwa dengan jumlah penerimaan yang cukup besar ini diperlukan suatu pengawasan terhadap prosedur dalam penggunaan keuangan tersebut. Oleh karena itu, kebijakan audit PNBP ini merupakan instrumen dalam rangka mengawasi penggunaan keuangan tersebut. Sebagaimana yang diamanatkan oleh Undang-undang Nomor 20 Tahun 1997 tentang Penerimaan Negara Bukan Pajak (PNBP) dan Peraturan Pemerintah Nomor 22 Tahun 1997 tentang Jenis dan Tata Cara Penyetoran PNB. Namun diperlukan juga komitmen dari para auditor, agar pengelolaan dana keuangan tersebut sesuai dengan kegunaannya dan tidak merugikan negara.

Berdasarkan penelitian awal terhadap pemanfaatan dana Penerimaan Negara Bukan Pajak (PNBP) dilingkungan unit satuan kerja Departemen Pendidikan Nasional RI khususnya PPG IPA Kota Bandung, permasalahan tersebut diduga karena implementasi yang belum efektif dari kebijakan audit PNBP tersebut. Hal ini 
dikarenakan masih banyak hambatan-hambatan, yaitu :

1. Pemahaman yang belum merata dan seragam tentang mekanisme pengelolaan PNBP pada kantor/Satuan Kerja dilingkungan Depdiknas.

2. Masih banyak jenis-jenis PNBP pada Kantor/Satuan Kerja dilingkungan Depdiknas belum disetorkan ke Kas Negara sesuai yang diamanatkan Undang-undang tersebut diatas.

3. Belum terbentuknya Dana Isian Kegiatan Suplemen (DIKS) Non Perguruan Tinggi Negeri.

4. Masih banyaknya potensi sumber-sumber PNBP pada Kantor/Satuan Kerja dilingkungan Depdiknas yang belum digali secara optimal dan dilaporkan sebagai sumber penerimaan.

Untuk mengatasi permasalahan diatas, diperlukan upaya implementasi audit yang mengacu kepada undang-undang dan peraturan pemerintah tersebut diatas. Dengan upaya tersebut diharapkan mekanisme penyetoran dan pemanfaatan dana yang bersumber dari PNBP tersebut dapat lebih transparan dan akuntabel, khususnya pada Pusat Pengembangan dan Penataran Guru IPA (PPG IPA) Bandung. Sehubungan dengan kebijakan audit tersebut, sesuai dengan penelitian yang dilakukanolehHartadi(2009) diharapkan dapat menutup kemungkinan untuk terjadinya implementation gap yaitu suatu keadaan dimana dalam proses kebijakan selalu akan terbuka kemungkinan terjadinya perbedaan antara apa yang diharapkan oleh pembuat kebijakan dengan apa yang sebenarnyaterjadi.

\section{Pengujian Hipotesis}

Sesuai dengan metode penelitian yang ditetapkan, pada bagian ini akan disajikan analisis data menggunakan analisis jalur (path analysis). Analisis jalur ini digunakan untuk mengetahui apakah terdapat pengaruh yang nyata dari variabel implementasi kebijakan audit penerimaan negara bukan pajak yang meliputi dimensi organisasi (X1), Interpretasi (X2), Aplikasi (X3) terhadap Kinerja Pengawasan Auditor (Y) pada PPPG IPA Kota Bandung.

Menggunakan analisis jalur ini, besarnya pengaruh yang diberikan implementasi kebijakan audit penerimaan negara bukan pajak terhadap kenerja pengawasan auditor dapat diketahui baik secara keseluruhan maupun secara parsial.

\section{Pengujian Hipotesis secara Parsial}

Pengujian secara parsial dilakukan ketika pengujian secara keseluruhan menolak hipotesis nol yang berarti sekurang-kurangnya ada satu koefisien jalur yang tidak sama dengan nol. Dari hasil uji di atas dapat dilihat bahwa pengujian secara simultan menolak $\mathrm{H}_{0}$ dan menerima $\mathrm{H}_{\mathrm{a}}$. oleh karena itu, pengujian hipotesis secara parsial ini dapat dilakukan. Pengujian ini dilakukan untuk mengetahui atau menguji pengaruh dari masing-masing variabel bebas terhadap variabel dependennya, apakah secara parsial signifikan 
atau tidak. Adapun hipotesisnya adalah sebagai berikut :

1. $\mathrm{H}_{0}: \mathrm{P}_{\mathrm{y}} \mathrm{X}_{1}=0$ Organisasi (X1) secara parsial tidak memiliki pengaruh yang signifikan terhadap Kinerja Pengawasan Auditor (Y) pada PPPG IPA Bandung.

$\mathrm{H}_{\mathrm{a}}: \mathrm{P}_{\mathrm{y}} \mathrm{X}_{1} \neq 0$

Organisasi (X1) secara parsial memiliki pengaruh yang signifikan terhadap Kinerja Pengawasan Auditor (Y) pada PPPG IPA Bandung.

2. $\mathrm{H}_{0}: \mathrm{P}_{\mathrm{y}} \mathrm{X}_{2}=0$

Interpretasi (X2) secara parsial tidak memiliki pengaruh yang signifikan terhadap Kinerja Pengawasan Auditor (Y) pada PPPG IPA Bandung.

$\mathrm{H}_{\mathrm{a}}: \mathrm{P}_{\mathrm{y}} \mathrm{X}_{2} \neq 0$

Interpretasi (X2) secara parsial memiliki pengaruh yang signifikan terhadap Kinerja Pengawasan Auditor (Y) pada PPPG IPA Bandung.

3. $\mathrm{H}_{0}: \mathrm{P}_{\mathrm{y}} \mathrm{X}_{3}=0$

Aplikasi (X3) secara parsial tidak memiliki pengaruh yang signifikan terhadap Kinerja Pengawasan Auditor (Y) pada PPPG IPA Bandung.

$\mathrm{H}_{\mathrm{a}}: \mathrm{P}_{\mathrm{y}} \mathrm{X}_{3} \neq 0$

Aplikasi (X3) secara parsial memiliki pengaruh yang signifikan terhadap Kinerja Pengawasan Auditor (Y) pada PPPG IPA Bandung.

Pengujian hipotesis parsial ini dilakukan dengan menggunakan uji t, dengan kaidah keputusan tolak $\mathrm{H}_{0}$ jika t-hitung $\leq \mathrm{t}$-tabel dan sebaliknya terima $\mathrm{H}_{0}$ jika t-hitung $\leq \mathrm{t}$-tabel. Hasil perhitungan menggunakan software SPSS 12,0 diperoleh sebagai berikut :

\section{Uji Koefisien Jalur secara Parsial}

\begin{tabular}{|c|c|c|c|c|c|}
\hline \multirow[b]{2}{*}{ Model } & \multicolumn{2}{|c|}{$\begin{array}{c}\text { Unstandardized } \\
\text { Coefficients }\end{array}$} & \multirow{2}{*}{$\begin{array}{c}\text { Standardized } \\
\text { Coefficients } \\
\text { Beta }\end{array}$} & \multirow{2}{*}{$\mathbf{T}$} & \multirow{2}{*}{ Sig. } \\
\hline & B & $\begin{array}{c}\text { Std. } \\
\text { Error }\end{array}$ & & & \\
\hline 1 (Constant) & 3,973 & 1,360 & & 2,922 & ,005 \\
\hline Organisasi &,- 295 &, 154 &,- 199 & $-1,918$ & ,060 \\
\hline Interpretasi & ,946 &, 149 &, 585 & 6,355 & ,000 \\
\hline Aplikasi & ,955 &, 152 &, 572 & 6,285 & ,000 \\
\hline
\end{tabular}

a Dependent Variable: Kinerja Audit

Sumber : Hasil pengolahan dengan SPSS 12,0

Dari tabel di atas, tampak bahwa hanya dua koefisien jalur yang memiliki nilai t-hitung yang lebih besar dari t-tabel $=1,980$, yaitu variabel bebas $\mathrm{X} 2=6,355$ dan $\mathrm{X} 3=6,285$. Sedangkan variabel bebas $\mathrm{X} 1$ nilai koefisien jalurnya memiliki t-hitung lebih kecil dari t-tabel yaitu sebesar -1,918. Hal ini menunjukkan, bahwa secara parsial hanya variabel X2 dan X3 yang memberikan pengaruh signifikan terhadap kinerja pengawasan auditor (Y) pada PPPG IPA Bandung, dengan demikian hipotesis nol $\left(\mathrm{H}_{0}\right)$ ditolak dan menerima hipotesis alternatif $\left(\mathrm{H}_{\mathrm{a}}\right)$. Sedangkan variabel bebas X1 tidak memberikan pengaruh signifikan terhadap kinerja pengawasan auditor, dengan demikian $\mathrm{H}_{0}$ tidak dapat ditolak. Walaupun secara simultan hasil uji $F$ menunujukkan pengaruh yang signifikan.

Gambar di atas juga digunakan untuk melihat nilai korelasi antar variabel bebas yaitu organisasi (X1), interpretasi (X2) dan aplikasi (X3). Hal ini diperlukan sebagai dasar analisis hubungan asosiatif antar variabel independen, sehingga dapat ditentukan strategi yang tepat dalam rangka peningkatan kinerja pengawasan auditor, hasil 
lengkap perhitungan korelasi tersebut adalah sebagai berikut :

a. Korelasi antara pengorganisasian dengan pengaplikasian sebesar 0,696, artinya bahwa kedua variabel tersebut merupakan dimensi dari variabel implementasi kebijakan audit yaitu sebesar $69,6 \%$.

b. Korelasi antara pengorganisasian dengan penginterpretasian sebesar 0,705 , artinya bahwa kedua variabel tersebut merupakan dimensi dari variabel implementasi kebijakan audit yaitu sebesar 0,705\%.

c. Korelasi antara penginterpretasian dengan pengaplikasian sebesar 0,586, menunjukkan nilai korelasi yang lemah, sehingga kedua variabel tersebut tidak cukup baik mendimensikan variabel implementasi kebijakan audit PNBP, yaitu hanya sebesar $58,6 \%$.

Oleh karena itu, dimensionalitas dari implementasi kebijakan audit PNBP yang paling baik dicerminkan oleh dimensi pengorganisasian dengan penginterpretasian dan pengorganisasian dengan pengaplikasian. Hal ini menunjukkan bahwa pengorganisasian merupakan faktor yang sangat penting dalam rangka pengimplementasian suatu kebijakan publik. Walaupun dari analisis pengaruh parsial faktor pengorganisasian ini tidak memiliki pengaruh yang signifikan terhadap kinerja pengawasan auditor. Dari gambar di atas, dapat dilihat juga nilai error (kesalahan pengganggu) sebesar 0,222 , artinya dengan pengaruh faktor lain tersebut sebesar $22,2 \%$, Dilihat dari nilai error sebesar 22,2 \% tersebut, dapat menjadi penyebab terjadinya penolakan terhadap $\mathrm{H}_{\mathrm{a}}$ dalam mengujian hipotesis secara parsial. Sehingga menyebabkan variabel independen X1 (pengorganisasian) tidak memiliki pengaruh yang signifikan terhadap kinerja pengawasan auditor.

1. lembaga dalam mengelola keuangan negara.

2. Auditor harus memiliki kemampuan dalam menciptakan suatu prosedur atau cara-cara yang benar-benar efisien dalam rangka melakukan audit atas pembukuan, catatan dan dokumen dari lembaga atau instansi pemerintah yang diperiksa berkaitan dengan pemungutan dan penggunaan keuangan negara, khususnya yang bersumber dari penerimaan negara bukan pajak.

Kedua aspek tersebut sesuai dengan konteks penelitian ini, yaitu sebagai landasan pokok dalam rangka menilai kinerja pengawasan auditor, terutama kinerja pengawasan yang berkaitan dengan hak keuangan negara sebagai tujuan dari dilakukannya audit penerimaan negara bukan pajak ini. Untuk itu ketiga aspek tersebut, perlu dikaji lebih lanjut, sehingga dapat ditentukan strategi yang tepat untuk melaksanakan implementasi kebijakan audit PNBP sehingga peningkatan kinerja pengawasan auditor dapat tercapai. Sementara itu, model implementasi pada kebijakan audit penerimaan negara bukan pajak, sebagai hasil temuan dari penelitian ini, masih 
memiliki keterbatasan dalam aplikasinya sebagai akibat adanya kelemahan-kelemahan pada :

Jadi untuk dapat mengatasi kelemahankelemahan dari pengimplementasian kebijakan audit penerimaan negara bukan pajak tersebut, dapat dilakukan dengan inventarisasi dari tugastugas pengawasan oleh auditor dan evaluasi pelaksanaan tugas tersebut. Kemudian langkah yang sangat penting adalah melakukan reformasi birokrasi dibidang auditasi ini. Perubahan yang paling penting adalah dari sisi budaya, karena untuk merubah budaya ini memerlukan proses yang tidak mudah dan memakan waktu yang lama. Sehingga apa yang menjadi paradigma pemerintahan birokrasi sekarang ini, yaitu cleon good governance dapat terwujud.

Sedangkan model dari kinerja pengawasan auditor masih mengalami kelemahan-kelemahan yang terjadi pada indikator-indikator sebagai berikut :

1. Fungsi pengawasan penggunaan keuangan negara dalam pengamanan hak keuangan negara. Hal ini menurut responden belum terlaksana dengan baik, oleh karena itu untuk mengatasinya perlu diterapkan azas audit yang transparansi dan akuntabel. Sehingga dapat meningkatkan kinerja pengawasan auditor.

2. Pelaksanaan sistem dan prosedur terhadap ketaatan dan kebijakan dalam rangka peningkatan kinerja pengawasan auditor.

3. Etika profesi yang dimiliki auditor terhadap ketaatan pada kebijakan dalam rangka peningkatan kinerja pengawasan auditor.
4. Kebenaran data dan informasi dalam proses administrasi auditing dalam rangka peningkatan kinerja pengawasan auditor.

\section{KESIMPULAN DAN SARAN}

\section{Kesimpulan}

Bertolak kepada hasil penelitian dan pembahasan yang telah diuraikan di atas, maka dapat ditarik kesimpulan bahwa:

Implementasi kebijakan audit penerimaan negara bukan pajak melalui dimensi-dimensi pengorganisasian, penginterpretasian dan pengaplikasian berpengaruh terhadap kinerja pengawasan auditor pada Pusat Pengembangan Penataran Guru IPA Kota Bandung. Pengaruh yang kuat tersebut mengandung makna bahwa semakin besar pemenuhan aspek-aspek organisasi, interpretasi dan aplikasi dalam implementasi kebijakan audit penerimaan negara bukan pajak maka semakin besar pula harapan terhadap peningkatan kinerja pengawasan auditor. Selanjutnya berdasarkan pengujian hipotesis secara parsial, menunjukkan bahwa hanya dua variabel independen (X2 dan X3) yang mempunyai pengaruh signifikan terhadap variabel dependen (Y). Sedangkan variable independen X1 nilai tidak memiliki pengaruh yang signifikan terhadap kinerja pengawasan auditor (Y) pada PPPG IPA Bandung.

\section{Saran}

Mengacu kepada kesimpulan penelitian yang telah dikemukakan di atas, beberapa saran sebagai 
masukan dan implikasi manajerial dari penelitian ini adalah :

a. Bahwa kinerja pengawasan auditor tidak saja dipengaruhi implementasi kebijakan audit penerimaan negara bukan pajak melalui dimensi-dimensi pengorganisasian, penginterpretasian dan pengaplikasian, tetapi juga dipengaruhi oleh variabel-variabel diluar kebijakan, telah menyebabkan lebih tingginya pengaruh faktor-faktor luar dalam rangka peningkatan kinerja pengawasan auditor. Variabel diluar kebijakan yang mempengaruhi proses implementasi tersebut, antara lain; (1) kondisi sosial ekonomi dan teknologi (2) dukungan publik (3) sikap dan sumber-sumber yang dimiliki kelompok-kelompok dukungan dari pejabat atasan (5) dukungan dan kemampuan kepemimpinan pejabat-pejabat pelaksana. Sehubungan dengan hasil dari pengujian hipotesis dalam rangka mengukur kinerja pengawasan auditor, hasil analisis penelitian tersebut menunjukkan bahwa aspek pengorganisasian gagal mendimensikan implementasi kebijakan audit PNBP dalam rangka pengukuran kinerja pengawasan oleh auditor.

b. Perlu dilakukan upaya-upaya reformasi birokrasi dilingkungan Kantor Pusat Pengembangan dan Penataran Guru (PPPG) IPA Kota Bandung sebagai upaya antisipatif dalam rangka mewujudkan clean and good government. Reformasi birokrasi tersebut, adalah sebuah proses perubahan paradigm pelaksanaan tugas-tugas dibidang pemerintahan. Perubahan yang paling penting adalah dari sisi budaya, karena untuk merubah budaya ini memerlukan proses yang tidak mudah dan memakan waktu yang lama. Sehingga apa yang menjadi paradigma pemerintahan birokrasi sekarang ini, yaitu cleon good governance dapat terwujud. Yaitu dengan mencegah Korupsi-Kolusi-Nepotisme yang mungkin akan terjadi dalam auditasi PNBP. Oleh karena itu, reformasi tersebut harus dilakukan secara berkesinambungan, menyeluruh dan menyentuh aspek struktural dan bersifat preventif-antisipatif serta mempertimbangkan aspek-aspek kesejahteraan pegawai.

\section{REFERENSI}

Alm, J., Jackson, B.R., dan McKee, M. 1993. Fiscal Echange, Collective Decisions Institututions, and Tas Compliance. Journal of Economic Behavior and Organization. Vol 2. No. 2: 285-303.

Carcello, J.V., \&Nagt, A.L. 2014.Client Size, Auditor Specialization and Fraudulent Financial Reporting.Managerial Auditing Journal. 19 (5): 651-668.

E. Kast, Fremont dan Rosenzweig, James (2010), Organisasi dan Manajemen (Edisi kedelapan), Jakarta, Bumi Aksara.

Hartadi, B. 2009. Pengaruh Fee Audit, Rotasi KAP, dan Reputasi Auditor terhadap Kualitas Audit di Bursa Efek Indonesia. 
Jurnal Ekonomi dan Keuangan. Akreditasi No. 110.

Herryanto, Marisa dan Agus Arianto Toly. 2013. Pengaruh Kesadaran Wajib Pajak, Kegiatan Sosialisasi Perpajakan, Dan Pemeriksaan Pajak Terhadap Penerimaan Pajak Penghasilan Di KPP Pratama Surabaya Sawahan. Tax \& Accounting Review. Vol 1. No 1.

Jones, Charles . O (2014), An Introduction to the Study of Public Policy (Third Edition), California, Wadswort, Inc.

Khomsiyah dan Indriontoro, Nur (2008), Pengaruh Orientasi Etika Terhadap Komitmen dan Sensivitas Etika Auditor Pemerintah di DKI Jakarta, Jurnal Riset Akuntansi Indonesia I, (I) 13-28

La Midjan dan Susanto, Azhar (2009), Sistem Pengendalian Intern, Bandung, Remaja Rosdakarya.

Margono, Kuncoro Tri (2005), Pengaruh Implementasi Kebijakan Audit Kepabeanan dan Cukai di Kawasan Berikat Terhadap Komitmen Auditor, Bandung, STIA LAN.

Prawiro. 2006. Keuangan Publik dan Daerah, Artifaduta Prakasa, Jakarta.

Rudi Pratono dan Desy Indah Lestari. 2010. Pengaruh Audit Fee, Jasa Selain Audit, Profil Kantor Akuntan Publik, Hubungan Audit yang Lama Antara KAP dengan Klien Terhadap Independensi Auditor dalam Kantor Akuntan Publik di Surabaya. Balance Economics, Bussiness, Management and Accounting Journal. Th. VII. No. 12.Published by Faculty of Economic Muhammadiyah Surabaya.ISSN 1693-9352. 